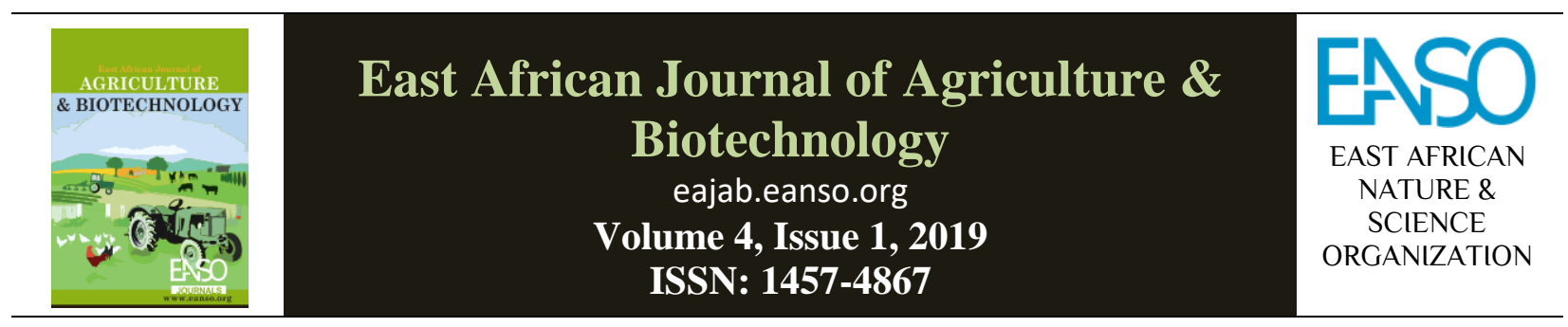

Original Article

\title{
EFFICACY OF GUAVA (PSIDIUM GUAJAVA) MULCH ALLELOPATHY IN CONTROLLING TOMATO (SOLANUM LYCOPERSICUM) WEEDS
}

\author{
Anthony Simiyu Mabele ${ }^{1} \&$ Dr. Millicent Florence Owuor Ndong' ${ }^{2}$ \\ ${ }^{1}$ Masinde Muliro University of Science and Technology, P.O. Box 190 - 50100, Kakamega, Kenya, mabeleanthony@gmail.com. \\ ${ }^{2}$ Masinde Muliro University of Science and Technology, P.O. Box 190 - 50100, Kakamega, Kenya, mndonga@mmust.ac.ke.
}

\section{Article history:}

Received: 30 Aug 2019

Accepted: 09 Sep 2019

Published: 18 Sep 2019

Keywords:

Allelopathy, Mulching,

Psidium guajava, Solanum lycopersicum, Weeds

\begin{abstract}
Tomato (Solanum lycopersicum) is one of the most important vegetable crop whose production involves the use of synthetic herbicides with detrimental impact on biodiversity. Allelopathy effectively controls horticultural crop weeds. Different plant parts (flowers, leaves, stems, bark, roots) have allelopathic activity that varies over a growing season when used as mulch. Mulching is a horticultural technique that protects the roots of plants from heat and cold by use of mulch to cover the soil surface around plants. Tomato production in Kakamega County is below 2\% and weeds are ranked high among the yield reducing factors. This study assessed the allelopathic effect of guava leaves mulch type $(18.0 \mathrm{~cm}$ thick) as a management tool for weed control in tomato crops and no mulch as control treatment with three most popular determinate tomato varieties. The mulch treatments were arranged as factorial in a Randomized Complete Block Design (RCBD) to minimize nonexperimental bias. Tomato variety sub-treatments were replicated three times in the experimental plots at Masinde Muliro University of Science and Technology $\left(0^{0} 17^{1} \mathrm{~N}, 34^{0} 45^{1} \mathrm{E}\right)$. The field project was conducted during the short rains and long rains season of 2016-2017. Data obtained was subjected to analysis of variance (ANOVA) using SAS software, version 9.3 at $\mathrm{p}<0.05$ confidence level. Least Significance Difference (LSD) was used to separate the means. Weed density incidence was significantly highest in control plots up to $100 \%$ and lowest in mulched plots (13.41\%). Allelopathic control of weeds sustains global food and nutrition security for future generations.
\end{abstract}

\section{INTRODUCTION}

Allelopathy has both beneficial and harmful impact from one plant to another plant in both crop and weed species through release of allelochemicals by root exudation, volatilization, residue decomposition and leaching among other processes in natural and artificial agricultural ecosystems (Gutierrez et al., 2008). Allelopathy technique is an effective and environmentally friendly method that controls weeds to achieve food sustainability in agricultural production systems. Allelopathy 
maintains ecological biodiversity through reduction of herbicide use by substituting them with natural allelochemicals. Allelopathy is widely studied in forest ecosystems where it affects many aspects of plant ecology like occurrence of weed-free zones, growth, plant succession, the structure of plant communities, dominance, diversity, and plant productivity (Muscolo et al., 2001; Awiti et al., 2007). Earlier forestry species evaluation reported negative allelopathic effects on food crops, but later research has identified forestry species with beneficial, neutral, or selective effects on crop plants (Chapla \& Campos, 2010). The poor regeneration of forest species, crop damage, yield reduction, replant problems for tree crops and occurrence of weed-free zones support these findings related to changes in vegetation pattern succession.

Tomato (Solanum lycopersicum) is a fruity vegetable rich in vitamins $\mathrm{A}, \mathrm{B}, \mathrm{C}$ and $\mathrm{E}$ that boosts the immune system of the body from multiple illness and fight against aging. Tomatoes are a source of minerals ( $\mathrm{K}$ and $\mathrm{Fe}$ ), antioxidants (lycopenes and carotenoids), phytochemicals (Phenylpropanoids and flavonoids) and phenolic compounds which have a key role in human nutrition to prevent cardiovascular, prostate, lung, stomach, pancreatic, colorectal, oesophageal, oral, breast, skin and cervical cancers and asthma (Nell \& Wessels, 2006). Tomato (S. lycopersicum) seeds contain proteins, chlorine and sulphur detoxifying agents for the liver. Crushed leaves of tomato ( $\mathrm{S}$. lycopersicum) contain nicotinic acid which acts as an antiseptic to infected areas of the body (Nell \& Wessels, 2006).

The leading African tomato (S. lycopersicum) producing countries include Egypt, Nigeria, Morocco, Tunisia, Algeria, Sudan, South Africa and Cameroon. Tomato is grown all over Kenya with an average yield of 60 tonnes per hectare when managed well, and is ranked $6^{\text {th }}$ in Africa with a total production of 559,680 tonnes annually (FAOSTAT, 2012). The major producing Counties in Kenya are Kirinyaga (14\%), Kajiado (9\%), Taita Taveta (7\%), Meru (5.6\%), Bungoma (5.5\%), Kiambu (5.2\%), Migori (4.6\%), Makueni (4.4\%), Homabay (3.3\%), Nakuru (2.7\%) and Machakos (2.6\%) (Sigei et al., 2014). In spite of its wide cultivation in Kenya, research findings indicate that the average yield of tomato (S. lycopersicum) is still very low in Kakamega County (2.3\%) and does not meet the consumers demand. Tomato production in Kakamega County is constrained by several abiotic and biotic stresses among which, pests, diseases and weeds are ranked high. Frequent manual cultivation of tomatoes in Kakamega County to remove weeds until the crop forms a canopy that minimizes weed competition is only a temporary control method because rapid re-growth of weeds occurs and the injured root and stem bases of young and quite mature tomato (S. lycopersicum) crops allow penetration of wound pathogens which may kill the crop.

Weeds are considered to be a serious problem because they compete for water, nutrients, light and space consequently causing great reduction of crop yields of up to $100 \%$ in severe cases (Singh \& Giri, 2001). To mitigate the residual effects of herbicide application in tomato (S. lycopersicum) farming, this study provides an alternative method to manage weeds through guava mulch type. Guava (Psidium guajava L.) is a member of the family Myrtaceae whose leaves contains volatile oils like quercetin, avicularin, guaijaverin, terpenoids, flavonoids, coumarins and cyanogenic acids among others (Muscolo et al., 2001).

Some studies have already identified guava allelopathic effects on other species like cucumber germination (Cucumis sativus), lettuce (L. sativa) germination and bristly foxtail (Setaria verticillata) (Chapla \& Campos, 2010). The beneficial effects of using mulching practice in vegetable and fruit cultivation include production of better-quality fruits with high yield, better economic returns to the farmer and minimal exposure to pesticides (Shashidar et al., 2000). Mulches are cost effective to farmers by reducing over-reliance on active ingredients in synthetic herbicides that kills many annual grasses and broad-leafed weeds and eliminates weeding costs.

\section{MATERIALS AND METHODS}

\section{Experimental Design}

The field experiment was conducted during the short rains season (August to December) of 2016 and long rains season (March to July) of 2017 at 
Masinde Muliro University of Science and Technology (MMUST) agricultural farm (N00 17.104; E034²45.874'; altitude $1561 \mathrm{~m}$ above sea level in Kakamega County, western Kenya. Soils in this region have nutrient composition of total phosphorus (18.9 $\mathrm{ppm})$, total nitrogen $(0.26 \%)$, organic carbon $(2.5 \%)$, potassium $(0.41$ cmolcKg-1 ${ }^{-1}$, sodium $\left(0.1 \mathrm{cmolcKg}^{-1}\right)$, calcium $(2.3$ cmolcKg $\left.{ }^{-1}\right)$, magnesium $\left(0.8 \mathrm{cmolcKg}^{-1}\right)$, zinc $(1.9$ ppm) and iron (0.37 ppm), with acidic $\mathrm{P}^{\mathrm{H}}$ of 4.2. The experiment was arranged in a Randomized Complete Block Design (RCBD) with three replications of the mulch treatments guava-A, guava-B and guava-C of $18.0 \mathrm{~cm}$ thick and no mulch as control. The three determinate tomato varieties of Fortune Maker-F1, Cal-J and MonicahF1 were sub-treatments arranged as factorial in the RCBD replications of 15 experimental plots. The tomato (S. lycopersicum) sub-treatments were completely randomized in the plots to minimize non-experimental bias during sampling for weeds (Table 1). Each experimental square plot size of 4 $\mathrm{m} \mathrm{x} 4 \mathrm{~m}$ had a distance of $1 \mathrm{~m}$ between the plots and $0.5 \mathrm{~m}$ buffer zones along the edges of each plot. Each experimental plot had 32 plants (n) totalling to 480 plants $(\mathrm{N})$. The tomato (S. lycopersicum) transplant spacing used was $0.5 \mathrm{~m}$ both for intra row and inter row to avoid overcrowding and reduce the confounding influence of the intended objective.

Table 1: Experimental study plots layout

\begin{tabular}{|c|c|c|c|c|c|c|}
\hline \multirow{5}{*}{ 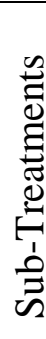 } & \multirow{5}{*}{  } & \multicolumn{5}{|c|}{ Main Treatments (Guava mulches and control) } \\
\hline & & Guava-A & Control-a & Guava-B & Control-b & Guava-C \\
\hline & & V1 & V3 & $\mathrm{V} 2$ & V1 & V2 \\
\hline & & $\mathrm{V} 2$ & V1 & V3 & $\mathrm{V} 2$ & V3 \\
\hline & & V3 & $\mathrm{V} 2$ & V1 & V3 & V1 \\
\hline
\end{tabular}

Key: $V_{1}$ - Fortune Maker- $F_{1}$ tomato variety; $V_{2}$ - Cal-J albeit "Kamongo" tomato variety; $V_{3}-$ Monicah- $F_{1}$ tomato variety

\section{Seedbed and Farm Management}

Certified seeds of the most commonly grown determinate tomato ( $S$. lycopersicum) varieties; Fortune Maker- $\mathrm{F}_{1}$, Cal-J and Monicah- $\mathrm{F}_{1}$ were purchased from the Kenya Seed Company Limited located within Kakamega Municipality. The seedlings were raised on the seedbed where weeds were manually uprooted. Transplanting was done late in the evening after rains in a well ploughed experimental farm plot. The mulches were set one day to planting, in a loosely well tilted soil devoid of weeds. Crop management involved pruning of side shoots and extreme flowers. Harvesting of mature fruits was done early in the morning when the temperatures were cool. The harvested tomatoes were sorted, graded and packed in clean well- ventilated wooden containers for transport to the market. The data obtained on weed density was subjected to ANOVA using SAS software, version 9.3 at $\mathrm{P}<0.05$ confidence level. The Least Significance Difference (LSD) was used to separate the means.

\section{RESULTS}

The mean weed density for control was statistically higher and different from the guava A, B and C mulches. Control experiments had up to $100 \%$ weed incidence that covered the entire plots in all the treatments and sub-treatments but $13.41 \%$ in guava mulch treatments. The mean incidences that have a common grouping letter are not significantly different at $\mathrm{P}<0.0052$ (Table 2; Figure 1). 
Table 2: Table 2: Mean weed incidence

\begin{tabular}{lllll}
\hline Mulch type & Mean & Coefficient of variation (cv) & F-value & P-value \\
\hline Guava-A & $0.8099^{\mathrm{a}}$ & 12.21205 & 7.45 & 0.0052 \\
Control-a & $4.8575^{\mathrm{b}}$ & & & \\
Guava-B & $1.0762^{\mathrm{cb}}$ & & & \\
Control-b & $4.5734^{\mathrm{c}}$ & & & \\
Guava-C & $1.1000^{\mathrm{d}}$ & & & \\
\hline Average mean & $\mathbf{2 . 4 8 3 4}$ & & & \\
\hline
\end{tabular}
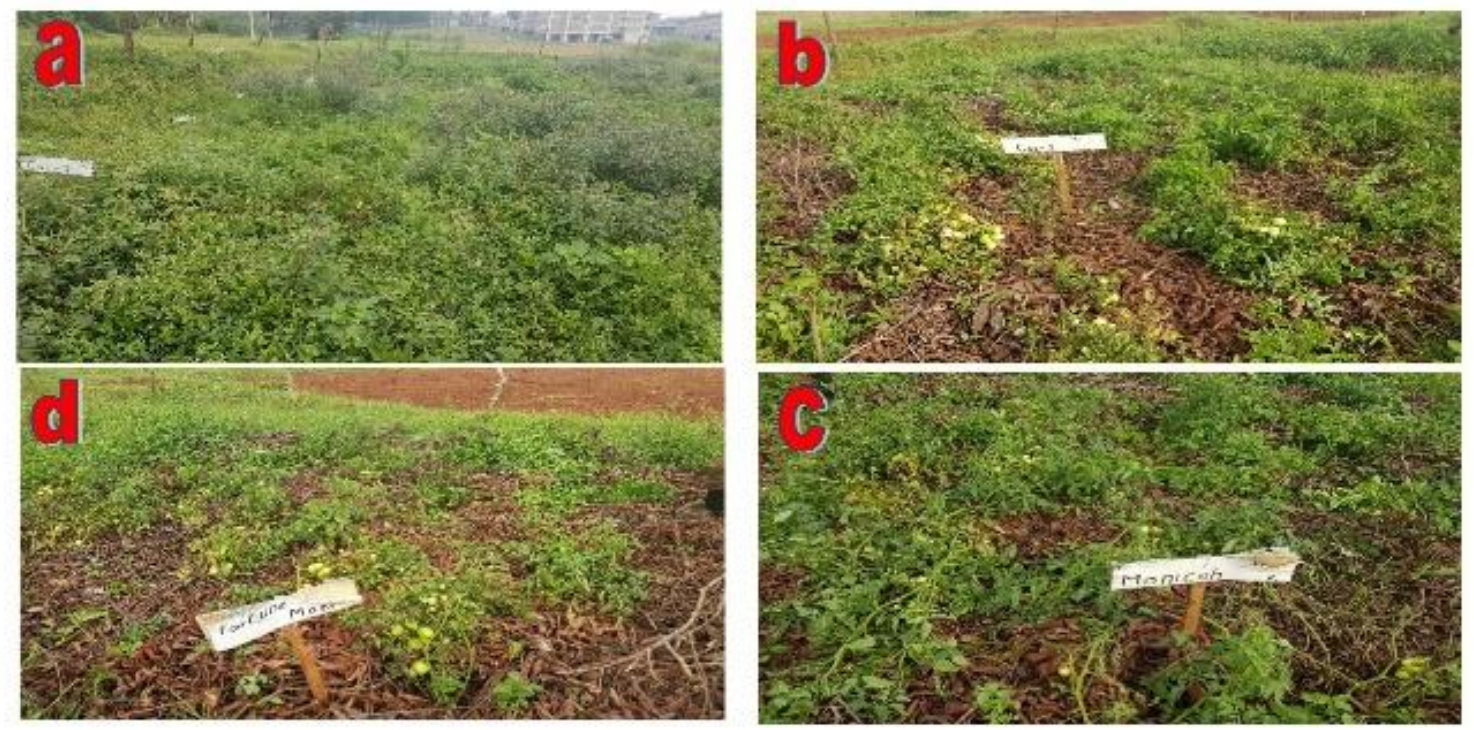

Figure 1: Mulch types efficacy observed upon application on some sub-treatments: 1: Control treatment; 2: Guava-A mulch type; 3: Guava-B mulch type; 4: Guava-C mulch type

\section{DISCUSSION}

The mean weed incidence was highest in control plots than guava mulch types. The guava mulch allelopathy efficacy inhibited weed growth through residue decomposition. The basic approach used in this study was allelopathic/simulatory effect of guava leaves and their capacity to suppress weeds. The guava leaves were potentially used to control weeds by mulching. Allelopathy effects of reduction in seed germination and seedling growth, originate from allelochemicals that persist in soil, affecting plants grown in succession. Allelochemicals are biodegradable than artificial herbicides, although they may also have undesirable effects on non-target species, necessitating ecological studies before widespread application in farming practices.

Allelopathy reduces chlorophyll complex pigment in photosynthetic membranes. Reduced chlorophyll content in allelopathic-treated plants may reduce chlorophyll accumulation in weeds through inhibition of chlorophyll synthesis, and stimulation of chlorophyll degradation (Zhou \& JQ, 2006). Mishra (2012) reported that phytotoxic mechanisms induced by allelochemicals from allelopathic compounds are the inhibition of photosynthesis and oxygen evolution through interactions with component of photosystem II which suppresses weed growth. Allelochemicals inhibit photosynthesis in intact plants resulting in 
depletion of food reserves and alteration of some enzymatic activities. Muscolo et al. (2001) reported that phenolic compounds like vanillic, p-coumeric and p-hydroxybenzoic acid were able to inhibit the enzymatic activity of weeds.

\section{CONCLUSION AND RECOMMENDATIONS}

In conclusion, this study used guava mulch types $\mathrm{A}$, $\mathrm{B}$ and $\mathrm{C}$ to control weeds in three determinate tomato (Solanum lycopersicum) varieties. The mulch types provided a more environmentally benign and durable weed control measures that blocked weed seed germination, suppressed the existing weeds and impacted positively on natural biodiversity.

Allelopathic traits should be incorporated from wild plants into crop plants through mulching or plant breeding methods to enhance the biosynthesis release of allelochemicals beneficial in weed control among horticultural crops. Allelochemicals/secondary metabolites suppress weeds from germinating and growing, further extensive studies on their efficacy are encouraged because this might be the only practical solution for adoption in biodiversity-friendly weed control method.

\section{ACKNOWLEDGEMENT}

This fieldwork experiment was conducted at Masinde Muliro University of Science and Technology (MMUST) agricultural farm.

\section{REFERENCES}

Awiti, A, Walsh, M., Shepherd, K., Kinyamario, J. 2007. Soil condition classification using infrared spectroscopy: A proposition for assessment of soil condition along a tropical forest-cropland. Cronosequence Geoderma, 143: 73-84.

Chapla, T. E. \& Campos, J. B. 2010. Allelopathic evidence in exotic guava (Psidium guajava L.). Braz. Arch. Biol. Technol. 53: 1359-1362.

FAOSTAT. 2012. Food and agricultural organization statistical database. Retrieved from http://www.faostat.org.
Gutierrez, R. M. P., Mitchell, S. \& Solis R.V. 2008. Psidium guajava: A review of its traditional uses, phytochemistry and pharmacology. $J$. Ethnopharm. 117: 1-27.

Mishra, A. 2012. Allelopathic interaction of L. camara leaf of extract on growth of $\mathrm{P}$. hysterophorus in seedling stage. International Journal of Plant Sciences. (In press).

Muscolo, A., Panuccio, M. R. \& Sidari, M. 2001. The effect of phenols on respiratory enzymes in seed germination respiratory enzyme activities during germination of Pinus laricio seeds treated with phenols extracted from different forest soils. Plant Growth Regulation. 35: 3135.

Nell, W. \& Wessels, B. (2006). Growing vegetables: A comprehensive guide on how to establish, maintain and manage a vegetable garden. University of the Free State. New Farmer and African Entrepreneur.

Shashidar, K.R., Bhakar, R.N., Priyadharshins, P. \& Chandrakumar, H.L. 2000. Effect of different organic mulches on $\mathrm{pH}$, organic carbon content and microbial status of soil and its influence on leave yield of M-5 Mulberry (Morus indica L.) under rainfed conditions. Current Biotica. 2:404-412.

Sigei, K. G., Ngeno, K. H., Kibe, M. A, Mwangi, M. \& Mutai, C. M. 2014. Challenges and strategies to improve tomato competitiveness along the tomato value chain in Kenya. International Journal of Business and Management. 9 (9): 1833-3850.

Singh, V. B. \& Giri, G. 2001. Influence of intercropping and weed-control measures on suppression of weeds and productivity of spring season sunflower (Helianthus annuus) and groundnut (Arachis hypogaea). Indian J. Agron. 46: 440-444.

Zhou, Y. H. \& JQ, Y. H. 2006. Allelochemicals and Photosynthesis. Nuria Pedrol and Luis Gonzalez, (eds). Allelopathy: A physiological process with ecological implications. Printed in the Netherlands. Manuel J. Reigosa. 127-139. 